\title{
A task-based approach to improving the communicative skills of university students learning Afrikaans as an additional language
}

\author{
Elbie Adendorff \\ Department of Afrikaans and Dutch, Stellenbosch University, South Africa \\ Email: elbie@sun.ac.za
}

\begin{abstract}
This paper reports on a qualitative study which was conducted with first-year Afrikaans Language Acquisition students in the Department of Afrikaans and Dutch of the Faculty of Arts and Social Sciences at Stellenbosch University, South Africa. The aim of the study was to determine how task-based activities contribute to the teaching and learning of communication skills in Afrikaans as an additional language. The aim therefore was not to present quantitative data, but to look at the attitudes and perceptions of the students and the lecturer through questionnaires and interviews. This study was explorative in nature and made use of task-based activities for the teaching of Afrikaans as an additional language to university students by using authentic material in pedagogic tasks. A secondary aim was to prove the acquisition of Afrikaans by way of spontaneous communication and interaction with the target language. The study was undertaken specifically on the teaching and learning of Afrikaans as an additional language in the context of the language acquisition classroom. The framework which was used and implemented in this study was a combination of qualitative research and the task-based approach to language teaching. A brief review is provided of the implementation of a taskbased syllabus after a needs-analysis was conducted with students registered for the Afrikaans Language Acquisition module at the university. In addition, a brief review will be given of the criteria used in the design of the syllabus, the teaching materials and the teaching programme. The outcome of the tasks was formulated according to what students needed to do with Afrikaans in the university context and is therefore focused on the students' needs. The focus was not on the formal linguistic aspects of the language but rather the functions thereof. The students were encouraged to participate and they learned Afrikaans by completing the tasks. The communicative potential of the task-based activities in the teaching programme is evaluated. This study showed that task-based activities contributed to the communication skills of students in the Afrikaans Language Acquisition class.
\end{abstract}

Keywords: Task-based teaching and learning, qualitative study, communication skills, Afrikaans language acquisition 


\section{Introduction}

The implementation of a multilingual language policy in higher education in South Africa (2002) requires the teaching and learning of Afrikaans as a second or additional language, which also includes the teaching of Afrikaans for specific purposes to adult learners. The latter has not received much attention in the South African context, especially in the form of research on the learning and teaching of Afrikaans for specific purposes in a university context. The research on Afrikaans as a second language has as its framework task-based language learning and teaching (Ellis 2003, Nunan 2004, Willis and Willis 2006, Samuda and Bygate 2008). Taskbased learning is a different way to teach languages. One way of helping students to learn and acquire a new language is to place them in real-life situations, where oral communication is essential for carrying out a specific task. One of the advantages of task-based learning is that it gets students to use their language skills at their current proficiency level, and develop their proficiency in the language by using it. Another advantage is that it places the focus of students on achieving a goal where language becomes a tool, making the use of language a necessity. Task-based learning is language learning by doing. By using this method, the focus of the learning process moves away from the teacher to the student. It provides a helpful framework for creating classes that are interesting and address students' needs.

The aim of this article is to present data on a qualitative study undertaken to determine how task-based activities contribute to the teaching and learning of communicative skills in Afrikaans as an additional language to university students. The aim of the study was to present qualitative data by looking at the attitudes and perceptions of the students through questionnaires and interviews. A secondary aim was to demonstrate the acquisition of Afrikaans by way of spontaneous communication and interaction with the target language.

The aim of the study focused on three research questions:

- Can a task-based approach contribute to the successful acquisition of Afrikaans?

- How does a task-based approach contribute to the successful acquisition of Afrikaans?

- Can a qualitative study be used to research task-based activities?

The article begins by first giving information on the broader research study before the methodology of the qualitative study is described. The tasks used in this study are then described before a brief review of the findings is given.

\section{Background}

This study forms part of a broader research study undertaken by Adendorff (2012a) in which a multi-perspective approach ${ }^{1}$ to a task-based syllabus design was followed. It formed part of the implementation of a task-based syllabus in the Afrikaans Language Acquisition module, which is presented in the Department of Afrikaans and Dutch at Stellenbosch University.

The aim of the multi-perspective approach was to research the full spectrum of approaches available in the design of a task-based syllabus for beginner learners of Afrikaans at a university. This research on a multi-perspective approach had as its aim the design of a

\footnotetext{
${ }^{1}$ This multi-perspective approach is described in Adendorff (2012b).
} 
defensible syllabus for Afrikaans at university level, as the interlanguage ${ }^{2}$ development of every student can be answered in each approach. The adequacy of the different approaches lies in the architecture of the compositionality and combination of the individual researchers' frameworks, of which each has its own elements of incompleteness regarding the components of complexity for the development of the students' interlanguage.

The study has as its framework the task-based approach to the teaching and learning of a language. Nunan (2003:216) gives a definition of task-based language teaching as "an approach to language teaching organized around tasks rather than language structures". One of the reasons for choosing the task-based approach is that it engages language learners in real language use in the classroom by designing and using tasks which require the language learners to use the language. Tasks are also used for syllabus design as it is, according to Nunan (2003:113), more than a methodological tool to be used in the classroom - "it is a central curriculum planning tool".

The researchers whose work on complexity in the design of a task-based syllabus was used in the broader study are Van Avermaet and Gysen (2006) and Duran and Ramaut (2006) on needsanalysis; Pica, Kangy and Falodun (1993) on task typology; Robinson (2001, 2003, 2005, 2007a, 2007b, 2010) on cognitive complexity, as well as his research on task conditions and task cognitive complexity in his Triadic Componential Framework; a linguistic analysis according to the research on AS units ${ }^{3}$ undertaken by Foster, Tonkyn and Wigglesworth (2000); the research of Michel (2011) on conjunctions as indicators of complexity; and the research of Loschky and Bley-Vroman (1993) on task utility, task essentialness and task naturalness.

The methodology of the research was six-fold. The starting point in the design of a task-based syllabus was a needs-analysis which was conducted through the use of questionnaires and interviews with university students. It indicated that students whose first language is not Afrikaans have to acquire communicative skills in Afrikaans in order to communicate effectively with fellow students and lecturers at the university. In the second place, the language-use situations and language tasks of the target task ${ }^{4}$ were described according to Van Avermaet and Gysen (2006:28). The parameters for the type task and the information processing levels were then determined, again using Van Avermaet and Gysen's (2006) study. By using the complexity scale of Duran and Ramaut (2006:51), the parameters of the task's complexity were determined. The task was then represented graphically on a complexity scale. The reason for doing this was to start determining the complexity level of the task to help with the grading thereof in the syllabus. Thirdly, the task was analysed according to the task typology of Pica et al. (1993) in order to see whether, and how, it would help with the interlanguage development of the students. Fourthly, the task conditions and then the task complexity were analysed according to Robinson's (2005) Triadic Componential Framework. Fifthly, the task was described linguistically by using Loschky and Bley-Vroman (1993), Foster et al. (2000) and Michel (2011). Lastly, a discussion of whether, and how, the different approaches

\footnotetext{
${ }^{2}$ Interlanguage is described by Ellis (2003:344) as "the system of L2 knowledge that a learner has built at a single stage of development". It is the language produced by learners in the course of second language acquisition.

${ }^{3}$ Foster et al. (2000) describes an analysis of speech units (AS units) as mainly a syntactic unit, and is a single speaker's utterance which consists of an independent clause or sub-clausal unit.

${ }^{4}$ A target task is a task found in the real world (Ellis 2003:351). It can be something like painting a fence, making a dinner reservation or filling in a form. It contrasts with pedagogic tasks which are tasks used in the classroom.
} 
supported one another followed to see how each approach could be used in the grading and sequencing of tasks in a task-based syllabus.

From this research, as further elaborated by Adendorff (2012c) and Adendorff(2010), the study described in this article evolved to investigate the use of pedagogic tasks in the classroom, and if and how they contribute to the teaching and learning of Afrikaans at university.

\section{Methodology}

The participants used for this study were the 48 first-year students enrolled in the Afrikaans Language Acquisition module of the Department of Afrikaans and Dutch in the Faculty of Arts and Social Sciences. The Language Acquisition module is a year module of 24 credits. It consists of three main lectures and two tutorials per week, each lasting 50 minutes in duration. The task-based activities were carried out mainly in the tutorial classes.

There were 16 male and 32 female students (see Figure 1) who were enrolled for different BA degrees, with many enrolled for the BA in Social Work (see Figure 2).

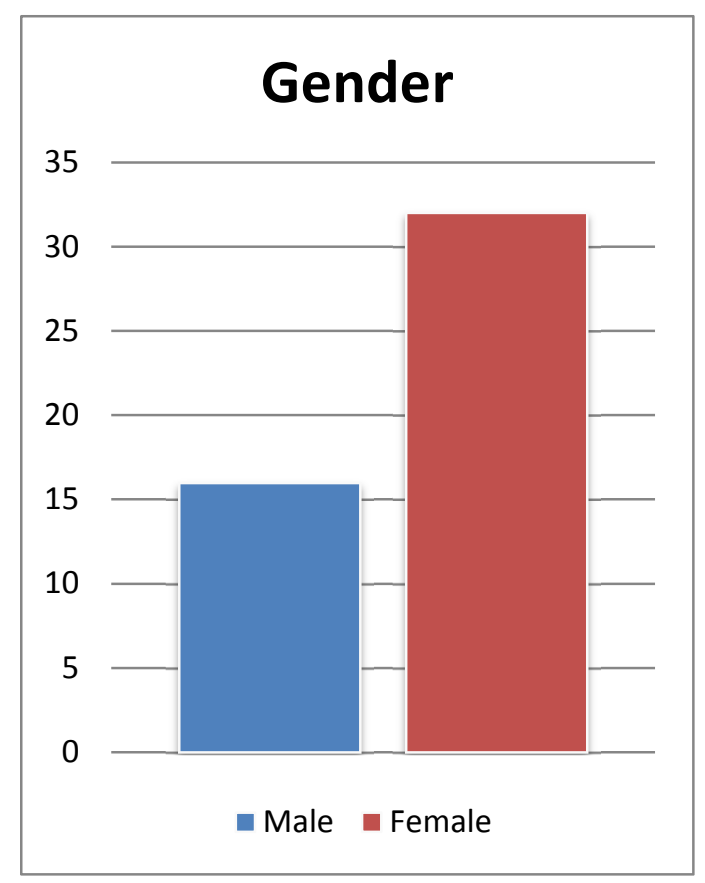

Figure 1. Distribution of gender

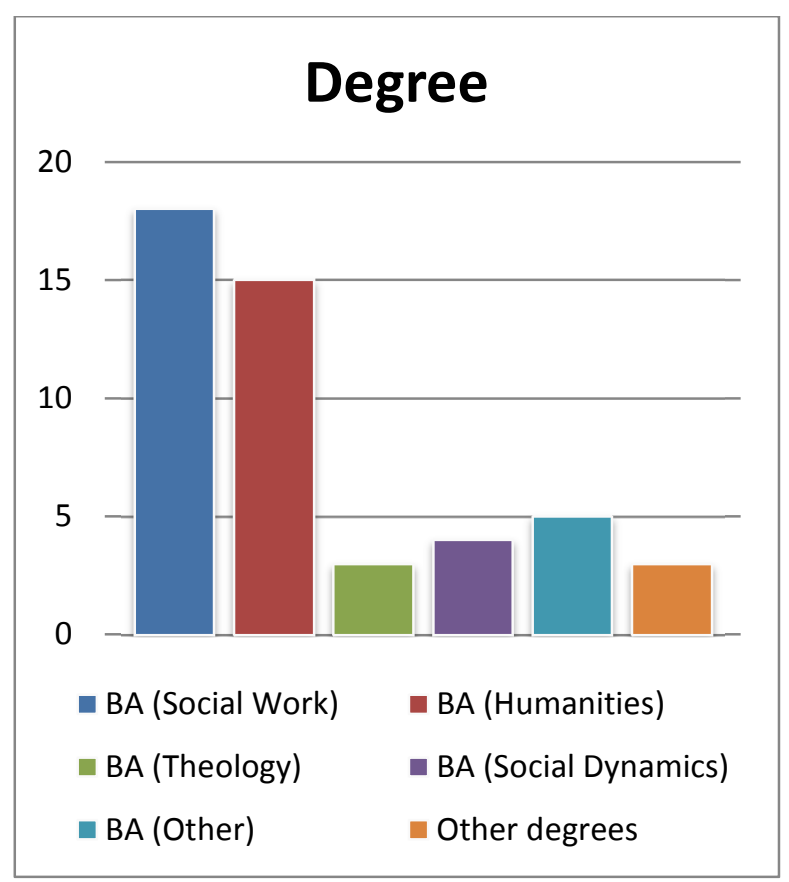

Figure 2. Distribution of respondents' degrees

The students were mostly from South Africa, but students from African countries like Rwanda, Zimbabwe and Nigeria, and from European countries, such as Italy, also formed part of the group. Although studies have been undertaken on the role of culture in language acquisition, this study did not focus on that aspect. It is also important to remember that language acquisition also involves the acquisition of the culture of the new language. In the Afrikaans Language Acquisition module, the different cultures are used as topics so that the students can learn more about each other. 


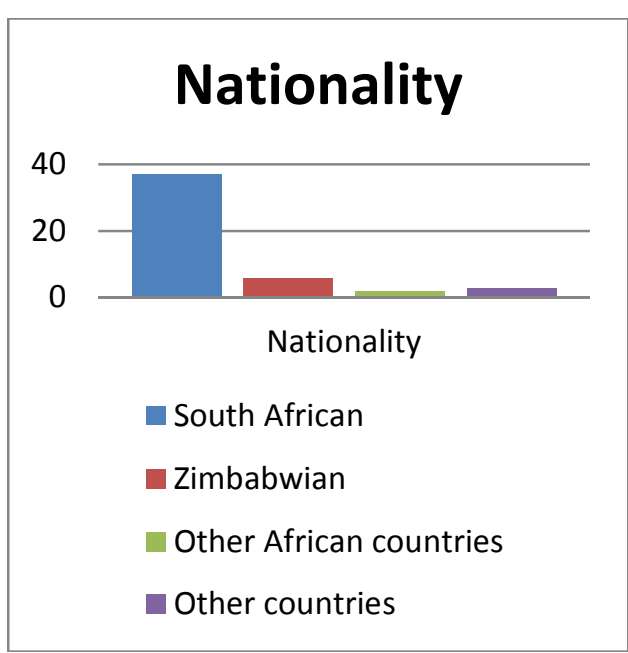

Figure 3. Distribution of nationalities

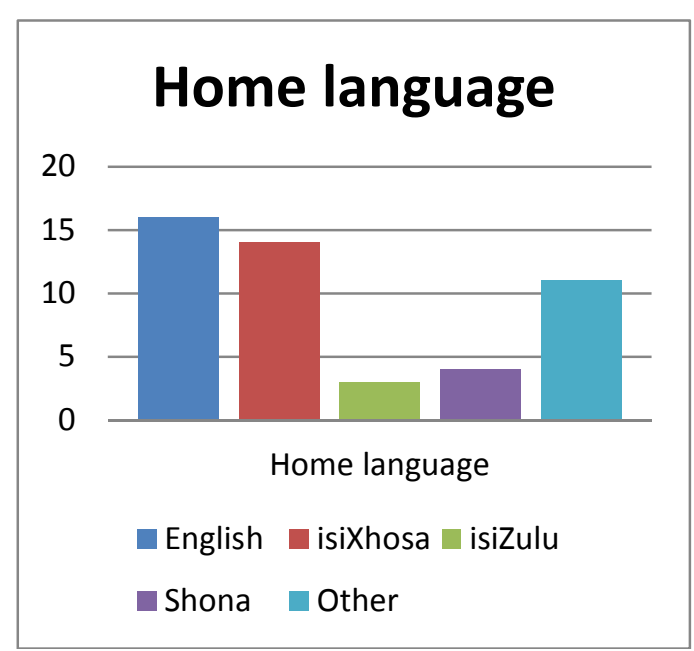

Figure 4. Distribution of home language

The South African students' home languages included isiXhosa, Shona, isiZulu and English. In task-based learning and teaching, and in other language acquisition approaches, the role of the first language has been studied, but the home language of the students taking part in this study was not taken into account.

The students did not have any prior exposure to Afrikaans before enrolling for the course. As part of the needs-analysis, they had to self-evaluate their Afrikaans language proficiency levels on the Common European Framework of Reference (CEFR) scales. Most of the students placed themselves on A1, the very basic proficiency level (for example, understanding basic greetings and words). Some could not even place themselves at this level and filled in "non-existent" in response to the question regarding how they would rate their general Afrikaans proficiency. Finally, a few of the students had very informal contact with Afrikaans in their home towns or cities.

\section{The study}

The four language skills were taken into account, from receptive (listening, reading and viewing) towards productive (speaking) skills. Each task contained new language knowledge. The tasks were intrinsically motivating which stemmed from the students' interest to communicate in the target language. The students' curiosity was aroused and they engaged actively in the tasks. Furthermore, the students had active roles in the tasks and they were encouraged to use the target language, Afrikaans. The tasks were completed individually and/or as a group, and were then graded and sequenced from concrete information tasks and here-andnow situations to more abstract information and there-and-then situations. Students were allowed to make mistakes as it is seen as part of the natural learning process.

Tasks can be described as activities where the target language, in this case Afrikaans, is used by the students for a communicative purpose (goal) in order to achieve an outcome - depending what the focus of the task is (i.e. reading, vocabulary, oral, problem-solving, decision-making). To determine how task-like a given activity was, the following questions were used as a guideline: 
- Does the activity engage students' interest?

- Is there a primary focus on meaning?

- Is there an outcome?

- Is success judged in terms of outcome? Is completion a priority?

- Does the activity relate to real world activities?

The notion of engagement was important in the tasks, as without engagement and genuine interests, there will be no focus on meaning. A task-based approach is a meaning-based approach. It means that the teacher (or in this case, the lecturer) does not control learner language as the focus is not on grammar (or form), but on successful communication or interaction. In the task-based approach, the students and the lecturer will at some time focus on language, not the correct linguistic form to use but rather on how the student expresses him/herself. More time needs to be spent on tasks which promote more communicative language use.

For the tasks to be successful, it was important to ensure that the students knew the final outcome of each one. Preparation time was also incorporated into some of the tasks to stimulate engagement, but other tasks were completed without this time period. The interaction patterns were different for each task; some were done individually, some in pairs or in whole-class situations. Roles, for instance chairperson or timekeeper, were sometimes assigned to students. Post-task activities included games, writing or oral tasks, but the main activity was reflection on the tasks by completing a questionnaire and/or being interviewed.

The tasks were structured according to Willis' (1996:155) framework of pre-task (preparation), task and task focus:

\section{PRE-TASK}

Teacher introduces topic, activities to activate the existing vocabulary or introduce the new vocabulary, gives examples of task completion and gives instructions on how to complete the task

$\operatorname{TASK}(\mathrm{S})$

Cycle/s of Task $>$ Planning $>$ Reporting back

TASK FOCUS

Moves from focus on meaning to focus on form, develops and enhances accuracy by using different focus activities (e.g. word analysis, semantic analysis, syntactic analysis)

\subsection{Task 1}

The first task took place over two tutorials about a month after the module began. The students looked at a picture depicting school life (see Figure 5). 


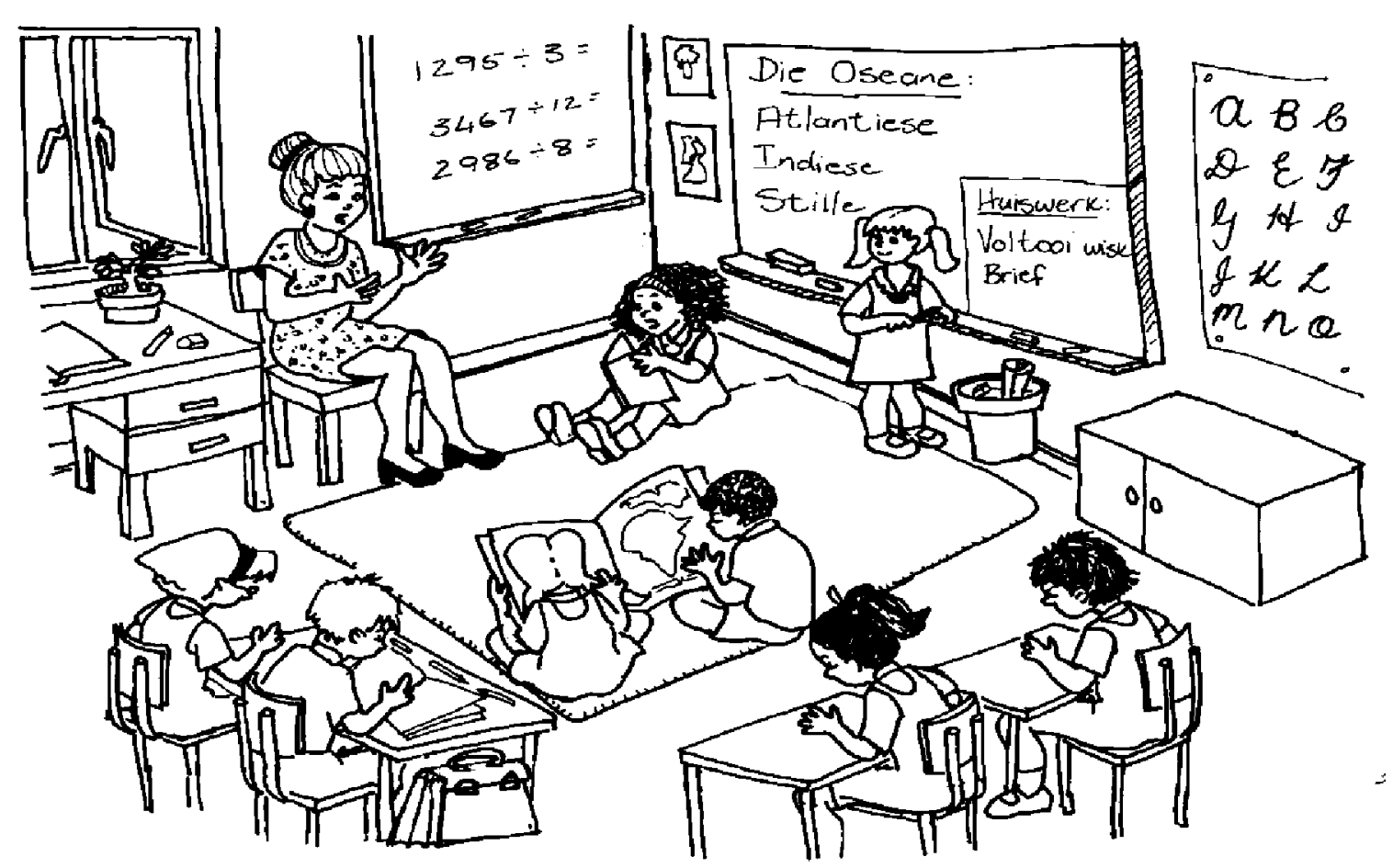

Figure 5. Picture for Task 1 depicting school life

The students had to work individually and had to identify objects and people in the picture, such as "onderwyser" ('teacher'), "lessenaar" ('desk') and "bordkryt" ('chalk'). The use of a dictionary was important as they had to look up the Afrikaans word in order to know the English one. After a certain time limit, students worked in pairs to compare their words and the number of objects and people they identified. Information transfer took place as they gave out information to the other students in the group. The whole class worked together to ensure that all the objects and people were identified. During all of these phases, the tutor repeated the words and gave the correct pronunciation. The students then had to repeat after her so that they practised the correct pronunciation. She also gave the plural and diminutive forms without explicitly focusing on the grammar rules regarding these forms in Afrikaans (for example, "stoel" ('chair'), "stoele" ('chairs'), and "stoeltjie" ('little chair')).

Next, the students were each given a verb on a flash card and then had to choose a picture of an item which connected with the verb, like "lees" ('read') and "'n boek" ('a book'), "sit" ('sit') and "'n stoel" ('a chair'). These separate words and pictures all linked back to the picture in Figure 5. Finally, the vocabulary was tested with a bingo game where they had to listen for the word and mark it off.

\subsection{Task 2}

Task 2 was carried out quite early on in the course and focused mainly on vocabulary. As a pretask, the students had to say which profession they were studying for and why. The students received pictures and words of different professions, four of which are given below as examples: 


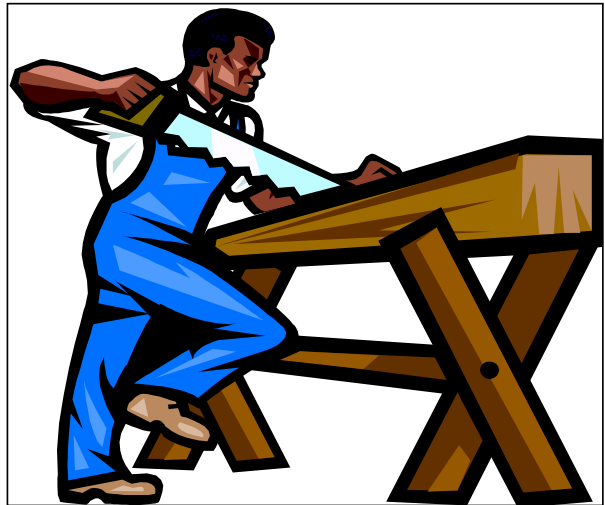

Figure 6. Skrynwerker ('joiner'/‘cabinetmaker’)

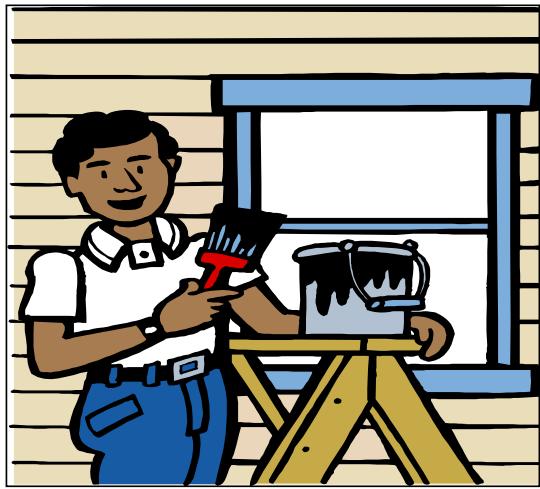

Figure 8. Verwer ('painter')

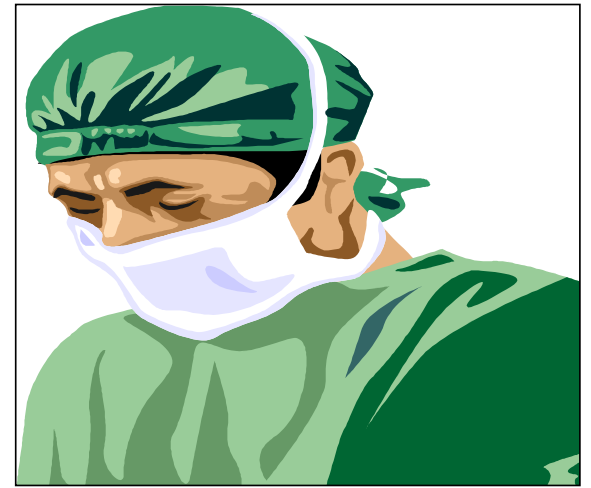

Figure 7. Dokter ('doctor')

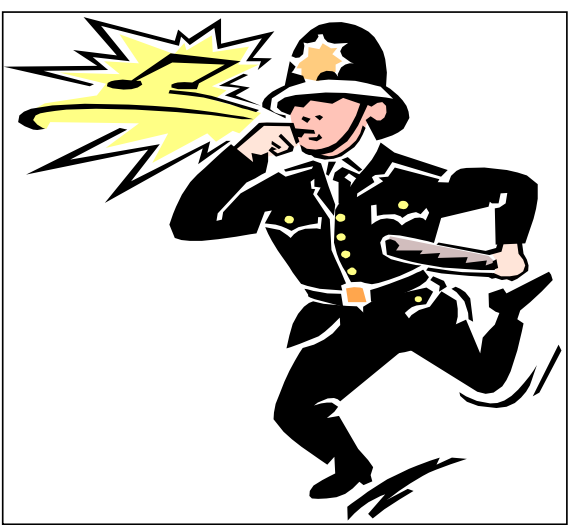

Figure 9. Polisieman ('policeman')

In groups of three or four, the students first had to identify the professions in English and then use the dictionary to obtain the correct Afrikaans terminology to pair the word and profession. They then received sentences like the ones given below, which they had to match correctly with a corresponding picture.

- 'n Skrynwerker is iemand wat houtwerk doen. ("A cabinetmaker is somebody who does woodwork.')

- 'n Dokter is iemand wat siek mense gesond maak. ('A doctor is somebody who heals sick people.')

- 'n Verwer is iemand wat mure van huise verf. ('A painter is somebody who paints the walls of houses.')

- 'n Polisieman is iemand wat misdadigers vang. ('A policeman is somebody who catches criminals.')

Following this, the students were required to write a similar sentence about their profession. These sentences were placed in a box from which each student then picked a random sentence, after which they had to walk around in the class and ask each other (for example) "Studeer jy om 'n maatskaplike werker te word?" ('Are you studying to become a social worker?'). 


\subsection{Task 3}

Task 3 took place over two tutorials about halfway through the module. The students listened to the following story once:

Ben en sy nuwe buurman, Sipho Malope, het buite in die tuin met mekaar gesels. Ben kom by die huis in en sê vir sy vrou dat die nuwe bure hulle die volgende aand vir ete genooi het. Babsie wonder of sy en Ben die Malope-gesin nie eerste moes oorgenooi het nie. Babsie dink sy is reg aangetrek. Indien hulle te formeel aangetrek is, gaan sy skaam kry. Babsie dink dat Miriam pragtig lyk in haar etniese klere. Miriam Malope sê vir haar gaste dat die ete reg is. Miriam verras die bure met die heerlikste kos wat sy gemaak het. Babsie behoort nie vrouens van ander kultuurgroepe te onderskat nie. In die toekoms kan sy by Miriam gaan kuier, dan kan hulle resepte uitruil. Die waarheid in die nuwe Suid-Afrika is: 'n Mens leer altyd iets nuuts by ander kultuurgroepe.

['Ben and his new neighbour, Sipho Malope, talked to each other outside in the garden. Ben comes into the house and says to his wife that the new neighbours have invited them over for dinner the next evening. Babsie wonders whether they should not have invited the Malope family for dinner first. Babsie thinks she is dressed correctly. If they are too formal, she will be ashamed. Babsie thinks that Miriam looks lovely in her ethnic clothes. Miriam Malope says to her guests that the dinner is ready. Miriam surprises her neighbours with the tastiest food that she had prepared. Babsie should not underestimate other cultures. In the future she can visit Miriam and they can exchange recipes. The truth in the new South Africa is: we always learn something new from other culture groups.' $]^{5}$

The students then received five pictures depicting this story (see Figure 10).
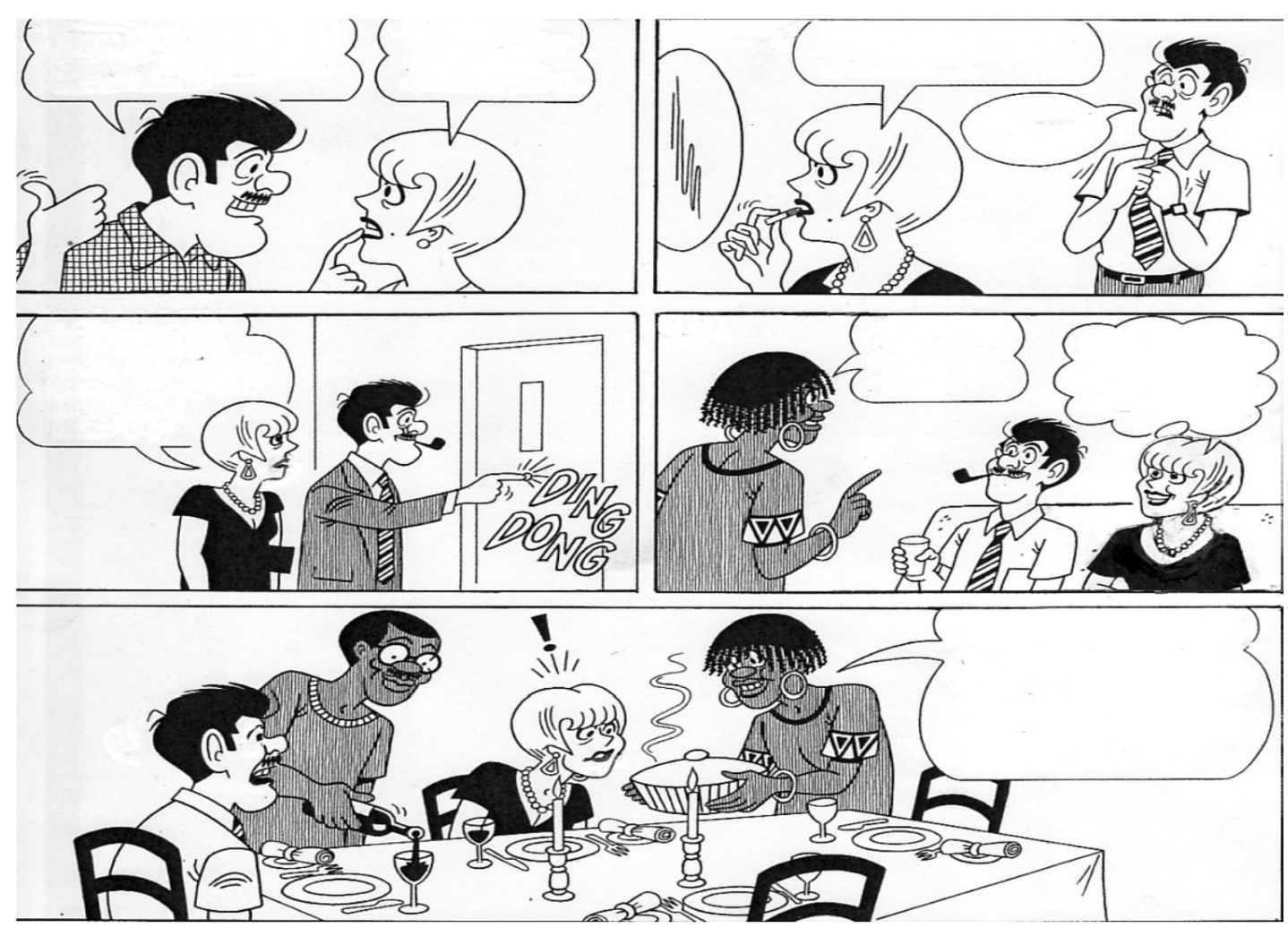

Figure 10. Dinner at the Malopes

\footnotetext{
${ }^{5}$ One aim of this story was to discuss cultural differences, as language learning also means learning something about the culture of the language speakers.
} 
After hearing the story, the students first had to work individually to put the pictures in the correct order to complete the story, and then check with their group partners if their picture order was correct. They then listened to the story again to check whether they had arranged the pictures correctly.

Next, the students received random alphabet letters and, in groups of four, had to build words which were connected to the story, for example "buurman" ('neighbour'), "eerste" ('first'). Following this, the students received parts of sentences which were connected to the story and had to work in pairs to complete the sentences. Finally, they had to complete the dialogue in the pictures individually according to what they could remember from the story.

\subsection{Task 4}

This task was a follow-up from task 3 and took place about six months after task 3 was completed. The students were divided into groups of four and the following Afrikaans dialogue was handed out ${ }^{6}$, which the tutor read aloud while the students followed along:

\section{'N GROEP TIENERS BESPREEK GEDURENDE POUSE HUL TOEKOMSTIGE BEROEPE EN VAKKEUSES}

Ryan: Kan julle dit glo! My Wiskunde-onnie, mnr. Zikalala, het gesê ek moet volgende jaar Wiskunde neem. Ek het $12 \%$ vir my Wiskunde-eksamen in Julie-maand behaal en nou wil hy hê ek moet die vak neem. Nooit!

Preshani: Ryan, moenie simpel wees nie! Dit is nie mnr. Zikalala wat jou so graag in sy klas wil hê nie; dis net hoe die nuwe onderwysstelsel werk, my skat. Almal moet Wiskunde as vak neem. Ek is seker dat hy baie bly sou wees as jy Wiskunde los!

Refilwe: Ek stem! (Almal lag) Dit ontstel my so, want ek wil 'n aktrise word (vol drama sit sy haar hand teen haar bors). Ek gaan NOOIT Wiskunde gebruik nie. Ek moet net hard aan my tale werk dan kry ek dalk werk op Isidingo, Sewende Laan of Muvhango. Ek wil nie soos daai mense wees wat net Engels kan praat nie. Ek gaan in matriek A's in Engels, Sesotho en Afrikaans behaal. Hou my dop!

Stefan: Ja, ja, Refilwe, en my ma is Charlize Theron! Ek hou van ernstige vakke: Wiskunde en Wetenskap. Ryan, ten minste kan jy en Refilwe Wiskundige Geletterdheid neem. Dink net, ek wil 'n ingenieur word en ek moet twéé tale neem. Dit is so onregverdig! Wie het in elk geval Sesotho en Afrikaans nodig? Engels is die besigheidstaal. Kan julle Refilwe as 'n aktrise sien? Sy kan nie eers 'n toespraak in die klas lewer sonder om histeries rond te hardloop nie. En het julle na haar klere gekyk? Net handelsmerke waar jy kyk! Hoe gaan sy soos 'n arm aktrise leef? Siestog!

(Hulle lag saam, behalwe Refilwe, wat Stefan net aangluur.)

Refilwe: Stefan, nee! Jy dink dat jy so slim is, maar jy is te vreklui om ooit 'n ingenieur te word. Jy moet liewers 'n ryk vrou kry sodat sy kan werk en jy by die huis kan sit, na die kinders kyk en die hele dag lank saam met hulle jou simpel rekenaarspeletjies speel.

Preshani: Kalmeer julle, ouens! Onthou net dat 'n mens nie net vakke kies wat jy dink jy dalk vir die toekoms nodig sal hê nie. Vakke wat verpligtend is, soos Wiskunde en jou tale, ontwikkel jou brein en laat jou beter dink. As enigiemand 'n probleem behoort te hê, is dit in elk geval ek! Ek wil my eie skoonheidsalon begin. Daar is amper niks hier op skool wat ek eendag gaan gebruik nie. Dalk is dit goed as ek tale aanleer, dan sal ek baie klante hê. Besigheidstudie is ook 'n goeie vak vir my om te kies, maar

\footnotetext{
${ }^{6}$ An English translation of this text appears directly after the Afrikaans original in this paper; note, however, that the students were only given the Afrikaans dialogue.
} 
my droom is om skool te los en vir 'n diploma in skoonheidsterapie in te skryf by een van die VOO (Verdere Onderwys en Opleiding) Kolleges, maar my pa wil niks daarvan hoor nie ...

Ryan: My pa sou mal word as ek vir hom sê ek gaan 'n akteur of 'n haarkapper word. Hy wil hê ek moet eendag sy besigheid oorneem en dus moet ek Wiskunde, Wetenskap en Rekeningkunde neem. Al my sterk vakke, natuurlik. Hy wil nie hoor dat ek daarvan droom om met diere te werk nie.

Refilwe: Ek het altyd geweet jy's 'n wilde dier, Ryan.

(Terwyl hulle nog skater, lui die klok.)

Stefan: Wel, ouens. Ek het nou Kuns en Kultuur en ons gaan vandag skilder. Ek is so rigtingloos soos mnr. Zikalala wanneer dit by kuns kom.

Almal: Sien julle tweede pouse.

\section{A GROUP OF TEENAGERS DISCUSS THEIR FUTURE PROFESSIONS AND SUBJECT CHOICES DURING BREAK TIME}

Ryan: Can you believe it! My Maths teacher, Mr. Zikalala, said to me that I must take Maths next year. I got $12 \%$ for my Maths exam in July and now he wants me to take the subject. Never!

Preshani: Ryan, don't be stupid! It is not Mr. Zikalala who so badly wants you in his class; it is how the new education system works, my dear. Everybody must take Maths as a subject. I am sure he would have been glad if you did not take Maths!

Refilwe: I agree! (Everybody laughs) It upsets me so because I want to be an actress (puts her hand against her chest in a dramatic pose). I am NEVER going to use Maths. I just need to work hard on my languages and then maybe I can act on Isidingo, Sewende Laan or Muvhango. I don't want to be like those people who can only speak English. I am going to get A's in English, Sesotho and Afrikaans in matric. Watch me!

Stefan: Yes, yes, Refilwe, and my mother is Charlize Theron! I prefer serious subjects like Maths and Science. Ryan, at least you and Refilwe can take Mathematical Literacy. Just think, I want to be an engineer and I have to take two languages as subjects. It is so unfair! In any case, who needs Sesotho and Afrikaans? English is the business language. Can you see Refilwe as an actress? She cannot even make a speech in class without running around hysterically. And did you see her clothes? Just brand names wherever you look. How will she live as a poor actress? Shame!

(They laugh, except Refilwe, who glares at Stefan.)

Refilwe: Stefan, no! You think that you are so intelligent, but you are too lazy to ever become an engineer. You should rather marry a rich woman so that she can work and you can stay at home to look after the children who can play your stupid computer games with you.

Preshani: Calm down, you lot! Remember that we do not only choose subjects that we think we will need for the future. Compulsory subjects, like Maths and your languages, develop your brain and let you think logically. If anybody should have a problem, it should in any case be me! I want to start my own beauty parlour. There is almost nothing here at school which I will use one day. Maybe it will be good to learn languages because then I shall have many clients. Business Studies is also a good subject for me to choose, but my dream to leave school and enrol for a diploma in beauty therapy at one of the FET (Further Education and Training) colleges is not going to happen as my father does not want to hear of it.

Ryan: My dad will get mad if I tell him I want to be an actress or hairdresser. He wants me to take over his business one day and therefore I need to take Maths, Science and Accountancy. All my best subjects, of course. He does not want to hear of my dream to work with animals.

Refilwe: I always knew you were a wild animal, Ryan.

(While they are all laughing, the bell goes.) 
Stefan: Well, guys. I have Arts and Culture now and we are going to paint today. I am as clueless as Mr. Zikalala when it comes to art.

Everybody: See you at second break.

Each group received a picture of a profession and an information sheet (see Figure 11) which they had to complete before reporting back to the class. First, they had to identify the profession, after which they had to write in the upper left block which subjects/qualifications are important for the profession. Then, in the upper right block, the students were required to write down the characteristics necessary for the profession. Finally, the students had to write down the pros and cons of the profession, in the bottom left and bottom right blocks, respectively.

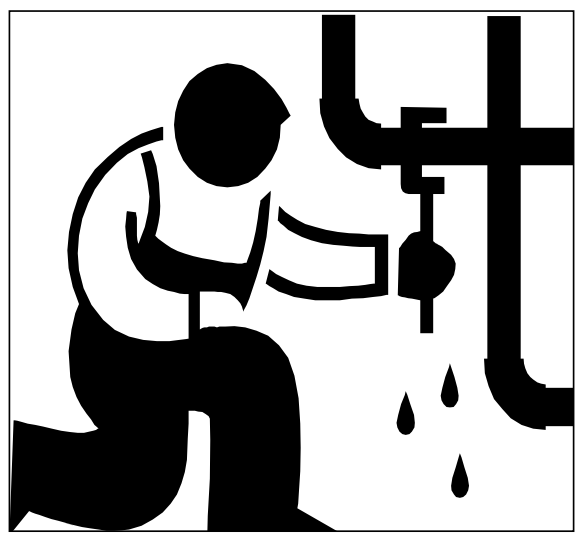

\begin{tabular}{|c|c|}
\hline Subjects/Qualifications & Characteristics \\
\hline Pros & Cons \\
\hline & \\
\hline
\end{tabular}

Figure 11. Picture of a profession and information sheet students received in Task 4

\subsection{Task 5}

\subsubsection{Pre-task}

For the pre-task of Task 5, the students were divided into groups of three and were required to choose a leader. The tutor introduced the topic, namely favourite school subjects. The students were asked what subjects they studied at school and they were written on the blackboard. The students were allowed to say them in English and then the tutor would ask the class if somebody knew the Afrikaans equivalents; if nobody knew them, she would then say them. When all the subjects were written down, the students had to classify them in groups, for example languages, sciences, etc. The tutor told the students her subjects, the ones she liked the most and why. The 
students were then tasked with telling the group which was their favourite subject and why, as well as the one they disliked the most and the reason why. They received three minutes preparation time before they started talking and they had to try and speak Afrikaans.

\subsubsection{Task}

The leader of the group had to allow every group member to talk for two minutes only, after which the leader was the last to speak. Every student had to give feedback on somebody else in the group, i.e. he or she had to repeat what a specific group member said (the group leader decided who talked about whom). This was designed to enhance the students' listening skills.

\subsubsection{Task focus}

Feedback was given to the whole group by the leader, with the aim of finding out which subjects were the most and which were the least preferred. Phrases such as "Ek hou van ..." ('I like ...'), "Ek was mal oor ..." ('I loved ...'), "Die vak wat ek verkies, is ..." ('The subject I prefer is ...') or "Ek het ... gehaat." ('I hated ...') had to be used. The tutor wrote these phrases on the blackboard and the reasons which were given were also written down. The aim of this was to see whether the male and female students liked and disliked the same or different subjects.

\subsubsection{Post-task}

The post-task involved the students and tutor anonymously completing a questionnaire containing the following questions:

- Did you enjoy doing the tasks in general?

- Which one of the tasks did you like the most?

- Which one did you like the least?

- Did you enjoy working with somebody? Why/Why not?

- Did you have to ask your team member(s) to help you with the task?

- Did you ask the tutor to help you?

- Do you feel that the tasks helped you with your vocabulary?

- Were all group members involved in the task?

- Do you think the task will help you improve your vocabulary?

- Do you think the task gave enough opportunity for meaningful communication?

The lecturer (researcher) also interviewed some of the students as well as the tutor. The questionnaire was used as a guideline for the interview in order to clarify some answers given by the students on the questionnaire.

\section{Findings}

It was clear from the questionnaire and the interviews that the students enjoyed the task-based activities. A few responses included: "I liked the interaction with the other students" and "I got to know my class members better". The task-based activities improved the communication skills of the students. For example, one student wrote: "I wanted to learn how to apply Afrikaans better, and that was achieved through these activities". It was found that the students were more confident in answering questions in the main lectures as their vocabulary improved. 
The gap between the students' knowledge and the new knowledge mainly concerned the vocabulary for communicating in Afrikaans. Most of the students expressed that it was their lack of Afrikaans vocabulary that hindered them understanding the tasks at first. The opportunity for interaction proved that those with a better command of the language helped those students who struggled, as exemplified in the following response by one student: "If I did not know an answer, I asked one of the other group members". The tasks led to better interaction between the individual students and the groups, as well as being inherently motivational. Consequently, the students were actively busy during the completion of the tasks.

These findings correspond with the findings of Kruger and Poser (2007) in which a research programme in a senior primary school was conducted using task-based activities. Kruger and Poser (2007:9-10) concluded that task-based activities improved the communication skills of the learners of Afrikaans in the senior phase. They also concluded that both the teachers and the learners enjoyed the activities. Although Kruger and Poser (2007) did not statistically look at and compare the differences between communicative teaching and formal form-focused teaching, they found that the learners had improved in their ability to identify nouns and verbs, and to formulate sentences with the help of task-based activities. It was also clear in their study that English had an influence on the learners' Afrikaans and that fossilization occurred.

\section{Conclusion}

This study has investigated the use of task-based activities in the learning and teaching of Afrikaans to university students. From the findings detailed in the previous section, certain conclusions can be made. Firstly, the task-based activities did indeed improve the communicative skills of the students. Secondly, most of the students reacted positively to the task activities ("My expectation was to learn some basic Afrikaans and I learnt that"); however, there were also some negative comments: "I expected to learn basic Afrikaans. It was not accomplished" and "It was very easy work to learn. I got frustrated with the other students who found it difficult". Finally, this study showed that a qualitative study can be undertaken to research task-based activities.

There are certain limitations of this study that need to be pointed out. Firstly, the use of students' first languages was not monitored; this could be a possibility for future research opportunities. Secondly, the influence and use of the tutor as a knowledge resource was also not investigated. Finally, this study only took place over several months and the time span might be too short to indicate automatisation of the target language as described by Robinson (2010); therefore, a longitudinal study is necessary.

The study was explorative in nature and made use of visual and concrete material. The questionnaires and interviews indicated that language learning is a holistic process. It showed that language is a social tool which can be used to negotiate meaning. The focus of the study was not on the formal linguistic aspects of language, but rather the function of language. Correct pronunciation and new vocabulary was taught in the context of the task-based activities, and modelling of task-based teaching strategies, as preferred by Ellis (2003), took place.

Despite the shortcomings and limited scope, the present study contributes to the learning and teaching of Afrikaans language acquisition to university students. 


\section{References}

Adendorff, E. 2010. 'n Behoefte-analise as eerste fase in die ontwerp van 'n taakgebaseerde sillabus vir Afrikaanstweedetaalonderrig op universiteitsvlak. LitNet Akademies 7(2): 220-240.

Adendorff, E. 2012a. Kompleksiteit in taakgebaseerde onderrig en leer van Afrikaans as tweede taal binne universiteitskonteks. $\mathrm{PhD}$ dissertation. Stellenbosch: University of Stellenbosch.

Adendorff, E. 2012b. 'n Multiperspektiefbenadering tot die ontwerp van 'n Afrikaanse taakgebaseerde sillabus op universiteitsvlak. LitNet Akademies 9(2): 613-652.

Adendorff, E. 2012c. Die omskakeling van werklikewêreld-take na pedagogiese take ten einde 'n taakgebaseerde sillabus te ontwerp. LitNet Akademies 9(3): 834-869.

Council for Cultural Co-operation, Education Committee, Modern Languages Division, Strasbourg. 2001. Common European framework of references for languages: Learning, teaching, assessment. Cambridge: Cambridge University Press.

Duran, G. and G. Ramaut. 2006. Tasks for absolute beginners and beyond: Developing and sequencing tasks at basic proficiency levels. In K. van den Branden (ed.) Task-based language education: From theory to practice. Cambridge: Cambridge University Press. pp. 47-75.

Ellis, R. 2003. Task-based language learning and teaching. Oxford: Oxford University Press.

Foster, P., P. Tonkyn and G. Wigglesworth. 2002. Measuring spoken language: A unit for all reason. Applied Linguistics 21(3): 354-375.

Kruger, E. and M. Poser. 2007. Taakgerigte aktiwiteite om die kommunikasievaardighede van addisioneleltaal-leerders in Afrikaans te ontwikkel. Tydskrif vir Taalonderrig 41(1): 1-13.

Loschky, L. and R. Bley-Vroman. 1993. Grammar and task-based methodology. In G. Crookes and S.M. Gass (eds.) Tasks and language learning: Integrating theory and practice. Clevedon: Multilingual Matters. pp. 123-167.

Ministry of Education. November 2002. Language policy for higher education. Available online: http://www/dhet.gov.za (Accessed 15 July 2010).

Nunan, D. 2004. Task-based language teaching. London: Cambridge University Press.

Pica, T., R. Kanagy and J. Falodun. 1993. Choosing and using communication tasks for second language instruction. In G. Crookes and S.M. Gass (eds.) Tasks and language learning: Integrating theory and practice. Clevedon: Multilingual Matters. pp. 9-34.

Robinson, P. 2001. Task complexity, cognitive resources, and syllabus design: A triadic framework for examining task influences on SLA. In P. Robinson (ed.) Cognition and second language instruction. Cambridge: Cambridge University Press. pp. 287-318. 
Robinson, P. 2003. The cognition hypothesis, task design, and adult task-based language learning. Second Language Studies 21(2): 45-105.

Robinson, P. 2005. Cognitive complexity and task sequencing: Studies in a componential framework for second language task design. International Review of Applied Linguistics in Language Teaching 43(1): 1-3.

Robinson, P. 2007a. Criteria for classifying and sequencing pedagogic tasks. In G.M.P. Mayo (ed.) Investigating tasks in formal language learning. Clevedon: Multilingual Matters. pp. 727.

Robinson, P. 2007b. Task complexity, theory of mind, and intentional reasoning: Effects on L2 speech production, interaction, uptake and perceptions of task difficulty. International Review of Applied Linguistics in Language Teaching 45(3): 193-213.

Robinson, P. 2010. Situating and distributing cognition across task demands: The SSARC model of pedagogic task sequencing. In M. Pütz and L. Sicola (eds.) Cognitive processing and second language acquisition: Inside the learner's mind. Amsterdam/Philadelphia: John Benjamins Publishing Company. pp. 243-268.

Samuda, V. and M. Bygate. 2008. Tasks in second language learning. Hampshire: Palgrave Macmillan.

Van Avermaet, P. and S. Gysen. 2006. From needs to tasks. Language learning needs as taskbased approach. In K. van den Branden (ed.) Task-based education: From theory to practice. Amsterdam/Philadelphia: John Benjamins. pp. 17-46.

Willis, J. 1996. A framework for task-based learning. London: Longman.

Willis, D. and J. Willis. 2006. Doing task-based teaching. Oxford: Oxford University Press. 